\title{
MODERNISMO E CULTURA POPULAR: O PROJETO ESTÉTICO DE MÁRIO DE ANDRADE
}

\author{
RICARDO LUIZ DE SOUZA ${ }^{1}$
}

\section{RESUMO}

O texto sintetiza e comenta aspectos básicos do projeto estético desenvolvido por Mário de Andrade e analisa a perspectiva pela qual Mário avalia o movimento modernista e a crítica muitas vezes amarga - por ele feita do modernismo e por extensão de sua própria obra. Ressalta finalmente, a importância que o conceito de cultura popular exerce na obra de Mário como fundamento para a criação de uma cultura brasileira e para a criação da própria cultura erudita.

palavras-chave: modernismo- cultura- literatura

\section{ABSTRACT}

The text synthecizes and comments basic aspects do aesthetic project developed by Mário de Andrade, and analyzes the perspective with which Mário evaluates the modernist movement and critical the many times bitter for it made do modernism and, for extension, of its proper workmanship. It standes out, finally, the importance that the concept of popular culture exerts in the workmanship of Mário, as bedding for the creation of a Brazilian culture and for the creation of the proper erudite culture.

key words: modernism - culture - literature

\footnotetext{
${ }^{1}$ Doutorando em História pela Universidade Federal de Minas Gerais. Publicou, entre outros, os seguintes artigos: "Trajetória de Joaquim Nabuco". Fronteiras, n.12. UFSC, 2004 e "A Virtude e a Piedade: sobre o conceito de burocracia em Max Weber". Gestare. n. 2, FEMM, 2005.
} 
Para Mário de Andrade, Nyi Erh é o principal músico contemporâneo. E quem foi Nyi Erh? Um cantor popular chinês, autor de canções que foram cantadas pelo seu povo e de uma canção especialmente chamada Levantai-vos, que se tornou um hino na luta contra o invasor japonês. Narrando sua história, então Mário conclui:

Nyi Erh é o maior dos músicos do nosso tempo. Ele soube compreender que em certos momentos decisivos da vida, a arte só tem que voluntariamente servir. A recomendação de Nyi Erh espalhou pela China centenas de corais patrióticos. Nyi Erh ajudou como ninguém, o levantamento do seu povo. Ninguém na China ignora o "Chee-Lai" que se tornou o hino nacional do milhão de guerrilheiros chins. Nyi Erh é o maior dos músicos do nosso tempo ${ }^{21}$.

O elogio ao compositor chinês ajuda a compreendermos o projeto estético proposto por Mário de Andrade. $\mathrm{O}$ artista deve manter uma atitude estética que redunde em permanente pesquisa para a partir dela buscar traduzir o espírito de sua época. Experimentalismo e preocupação social terminam por fundir-se no fim deste caminho, permitindo a satisfação de uma exigência definida por Lafetá: assumir essa postura significará, então ao mesmo tempo lançar-se para as experimentações da matéria e guardar um fundo ético incorruptível ${ }^{3}$.

O artista para Mário é político, mas não no sentido convencional. É político, não porque se envolva em movimentos políticos e busque organizá-los, mas porque cria esteticamente um

\footnotetext{
${ }^{2}$ ANDRADE, Mário de. Mundo musical in COLI, Jorge - Música final: Mário de Andrade e sua coluna jornalística. Campinas, Editora da UNICAMP, 1998, p.33

${ }^{3}$ LAFETÁ, João Luiz. 1930: a crítica e o modernismo. São Paulo, Duas Cidades/Editora 34, 2000, p.212. 
mundo perfeito e revolta-se contra a disparidade entre o mundo real e o mundo perfeito existentes apenas através de sua arte. Tomando Chopin como paradigma deste artista, Mário busca definir seu papel:

Não the cabe enquanto artista ser político, distribuir bênçãos, perdões e consolos, nem organizar ou dirigir fábricas, nem matar nas guerras e revoluções. Porque ele não vive de sua própria vida, mas da vida da obra de arte. É o que o torna um ser particularíssimo, mas por isto mesmo que pretende a beleza e a recria em sua criatura, ele é o revoltado por excelência contra os defeitos e as feiúras da vida, contra as injustiças, as falsificações, contra as mentiras sociais, as desgraças todas ${ }^{4}$.

E Mário chega ao final de sua vida definindo a arte como um compromisso inadiável e sem alternativas. E assim ele se retrata, a partir desta definição: há nesta rua Lopes Chaves um ridículo homem que chegou à convicção que neste momento culminante da vida, toda arte é pueril, todo indivíduo que não se sacrificar totalmente pela vida coletiva humana é um canalha, é um vendido, é um canalha ${ }^{5}$

Postula-se a necessidade, então de uma atitude ética na qual vaidades artísticas e atitudes de

isolamento devam ceder à necessidade de coletivizar o seu destino. Uma necessidade que o levaria ao engajamento, afinal desastroso, no Departamento de Cultura da Municipalidade de

\footnotetext{
${ }^{4}$ ANDRADE, Mário de. Atualidade de Chopin in Separata da Revista do Arquivo. Num. LXXXVI. São Paulo, Departamento de Cultura, 1942, p.14.
} 
São Paulo entre 1935 e 1937, do qual seria demitido por perseguições políticas e denúncias infundadas, e à revisão do modernismo, visto como uma etapa necessária de destruição e que sofreu afinal da vaidade e do isolamento por ele criticado.

O conceito de arte ou poesia social é, porém, criticado por Mário que a define como poema de circunstância ou arte de combate. Não que tal tipo de arte inexista: simplesmente toda arte é social, interessa à coletividade mesmo se preocupando exclusivamente com o artista e suas reações ${ }^{6}$.

Sua própria função de literato o incomoda quando confrontada diretamente com a miséria nordestina e ele confessa: eu tenho a coragem de confessar que gosto de literatura. Tenho feito e continuarei a fazer muita literatura. Aqui não. Repugna minha sinceridade de homem fazer literatura diante desta monstruosidade de grandezas que é a seca sertaneja do Nordeste ${ }^{7}$.

A ética e a estética andradeanas são, finalmente, de fundo religioso e não podem ser compreendidas fora deste contexto. Em poema da Paulicéia desvairada Mário já confessa: Deus! Creio em Ti ! Creio na tua Bíblia ${ }^{8}$.

Mário reafirma-se permanentemente como católico, como ao indagar sobre o catolicismo de Fernando Sabino: eu também sou de formação católica, acredito vorazmente em Deus, e por maiores que sejam os meus descaminhos, sei que morrerei ( se morte consciente) em estado católico ${ }^{9}$.

\footnotetext{
${ }^{5}$ ANDRADE, Mário de. Cartas a um jovem escritor/de Mário de Andrade a Fernando Sabino. Rio de Janeiro, Record, 1981, p.128.

${ }^{6}$ ANDRADE, Mário de. Querida Henriqueta: cartas de Mário de Andrade a Henriqueta Lisboa . Rio de Janeiro, José Olympio, 1991, p.156

${ }^{7}$ ANDRADE, Mário de. O turista aprendiz. São Paulo, Duas Cidades, 1983, p.301

${ }^{8}$ ANDRADE, Mário de. Poesias completas, São Paulo, Martins, 1974, p.50

${ }^{9}$ ANDRADE, Mário de. Cartas a um jovem escritor/de Mário de Andrade a Fernando Sabino. Op. Cit.p.30 
A partir de 1933, Mário aceita a existência de um binômio marxismo-cristianismo, ainda que o ajustamento a ser feito passe mais, como acentua Lopez, pela vontade de ser marxista. E ele como Lopez conclui: pensa ser marxista e pensa ser católico ao mesmo tempo em que reconhece não ser nenhum dos dois ${ }^{10}$.

E o horror da Segunda Guerra reafirma sua crença em Deus como um meio de compreender o incompreensível e, em carta a Sérgio Milliet, ele afirma: cada vez mais e deslumbrantemente eu creio em Deus. Dê você, Sérgio, conforme as suas idéias e princípios o nome que quiser, fatalidade, destino, ao que chamo de Deus - mas repare Sérgio, que o que está acontecendo no mundo, simplesmente não é possível! Não é possível sem a intervenção de um elemento qualquer predestinador ${ }^{11}$.

Cristão, Mário faz talvez ou quem sabe devido a sua condição de cristão uma crítica forte ao catolicismo brasileiro. Sua crítica refere-se ao caráter superficial de tal catolicismo: $a$ religiosidade se desenvolveu. A catolicidade se corroeu por dentro e ficou apenas uma casquinha epidérmica ${ }^{12}$. Mas tal crítica aprofunda-se e ganha um sentido de identidade, quando Mário associa características negativas do catolicismo brasileiro à ausência de uma identidade nacional. Tais características refletem e traduzem tal ausência. E o que é mais grave: o catolicismo brasileiro, devido a tais características torna-se incapaz de atuar como elemento capaz de agir sobre as consequiências nefastas desta ausência. Tal catolicismo, desta forma, não diminui em nada o egotismo, não coíbe a descaracterização moral, não socializa, não nacionaliza, não funde, não cria uma unanimidade ${ }^{13}$. Não age, portanto, como um

\footnotetext{
${ }^{10}$ LOPEZ, Telê Porto Ancona. Mário de Andrade: ramais e caminhos. São Paulo, Duas Cidades, 1972, p.71

${ }^{11}$ DUARTE, Paulo. Mário de Andrade por ele mesmo. São Paulo, HUCITEC/Secretaria da Cultura, Ciência e Tecnologia do Estado de São Paulo, 1977, p.333

${ }^{12}$ ANDRADE, Mário de. Aspectos da literatura brasileira. São Paulo, Martins, 1943, p.24

${ }^{13}$ ANDRADE, Mário de. Aspectos da literatura brasileira. Op. Cit., p.22
} 
elemento catalisador capaz de criar a síntese nacional cuja existência Mário define como urgente.

Mário é um cristão que vê no cristianismo praticado no Brasil um sinal de incultura, e que o critica como tal a partir por exemplo da caridade cristã tal como é aqui praticada: uma caridade que nasce do medo de ir para o inferno, uma caridade assustada, supersticiosa, contraproducente: dá-se ao incapaz que vai morrer, recusa-se ao capaz que vai fazer ${ }^{14}$.

A crítica de Mário ao catolicismo refere-se, principalmente, ao que ele considera o caráter consolador e por isto conformista da religião. É uma crítica que ele delineia com clareza em carta a João Etienne Filho escrita em 1944:

Quis dizer que o catolicismo que provoca em nós a atitude terrestre "este vale de lágrimas" e "com minha Mãe estarei na santa glória um dia” como atitude terrestre e conformista. Consola. É um defeito, um erro, um perigo, que o Catolicismo com C grande não aprova. Cuidado com o Catolicismo consolador. Não tem nada para deixar o indivíduo mais capaz de hipocrisia, de mediocridade, de amargura, de humildade falsa. E de amargura ${ }^{15}$.

Trata-se de um catolicismo, enfim, que contraria a ética de compromisso adotada por Mário justamente a partir da adoção de valores cristãos. Ele defende pelo contrário, um catolicismo que se afaste e não se deixe contaminar pelo cheiro de mofo de certos padres demasiado bons,

\footnotetext{
${ }^{14}$ ANDRADE, Mário de. Aspectos da música brasileira. São Paulo, Martins, 1965, p.241

${ }^{15}$ ETTIENE FILHO, João. Mário de Andrade: cartas do irmão maior. Belo Horizonte, Mazza/Belas Artes, 1994, p.35 
e que evite o martírio pelo gosto da morte, mas o aceite, se necessário, a partir da defesa da $\operatorname{vida}^{16}$.

A Civilização Cristã está morta e Jesus foi deposto pela Igreja que o trancafiou em um muro ao associar-se ao fascismo. Cristo foi expulso deste mundo pela Igreja, que se refugiou nele e transformou-se numa instituição alheia aos valores cristãos. Cristo está morto e deposto, mas Mário exclama: ora graças a Deus!... Morto e deposto, Jesus se libertou enfim. Agora é um deus unicamente divino ${ }^{17}$. Escrito em 1929 e sendo uma evidente crítica ao Tratado de Latrão, este trecho esclarece a religiosidade do autor. Neste sentido, Mário é cristão e anti-clerical também.

Mas o ateísmo termina sendo para ele, algo não apenas incompreensível, mas incompatível com a própria vida, a ponto dele afirmar:

Você sabe o que mais me assombra nos materialistas? É não se suicidarem todos eles! Porque não se suicidam! Sem uma significação superior, e esta só pode ser Deus, a vida é uma coisa completamente sem significação para a inteligência e esta só pode concluir pela bala na cabeça. Ou o cianureto de potássio $^{18}$.

E em carta de 1923 ele explica sua relação com Deus:

O oposto de felicidade é ateísmo. Não sou místico. Não tenho êxtases. Deus não me deslumbra nem me atemoriza. É um velho camarada cotidiano. Forte... Deus

\footnotetext{
${ }^{16}$ ETTIENE FILHO, João. Mário de Andrade: cartas do irmão maior.Op. Cit., p.63

${ }^{17}$ ANDRADE, Mário de. Táxi e crônicas no Diário Nacional. São Paulo, Duas Cidades, 1976, p.61-4 
é forte, rijo. Incansável. Tenho muita confiança nele. Há entre nós essa tácita, maravilhosa união de pessoas que às vezes passam anos sem se ver, sem se escrever. Um belo dia encontram-se. Tu por aqui! Como vais? E são sempre as mesmas. Poderão dizer de um todo mal possível à outra e que seja tudo verdade. Esta outra conservar-se-á sempre a mesma. Eis aí minhas relações atuais com Deus $^{19}$.

Tais relações iriam, ao que tudo indica, manterem-se inalteradas ao longo dos anos de tal forma que, oito anos depois, a crença em Deus seria reafirmada por ele em termos muito semelhantes: eu acredito certamente em Deus, sei que isso é incontestável dentro de mim. Uma crença primária, ingênua, bruta, inviolável, permanente, não carecendo de provas intelectuais, sinto Deus. Sem misticismo nenhum, sinto Deus ${ }^{20}$.

Se Mário é cristão, e sua moral e ética não podem ser compreendidas separadamente deste fato de sua vida e obra, por sua vez, não podem ser compreendidas separadamente desta e desta ética - o cristianismo não pode servir como refúgio, consolo ou álibi. Deve pelo contrário, atuar como chamada ao combate, o que o leva a afirmar: nós temos que viver a nossa terra redonda, temos que "combater" a nossa terra redonda. O prêmio virá depois,

\footnotetext{
${ }^{18}$ ANDRADE, Mário de. Querida Henriqueta: cartas de Mário de Andrade a Henriqueta Lisboa . Op. Cit., p.80

${ }^{19}$ MORAES, Marcos Antônio de ( Org. ). Correspondência Mário de Andrade \& Manuel Bandeira. São Paulo, EDUSP/IEB, 2001, p.100

${ }^{20}$ MORAES, Marcos Antônio de ( Org. ). Correspondência Mário de Andrade \& Manuel Bandeira. Op. Cit., p.594
} 
mas o combate é aqui e por causa daqui ${ }^{21}$. Desta postura, portanto, deriva sua moral e sua ética. Mais que isto, tal postura as justificam e as sintetizam.

Tomo agora, a seguinte questão como ponto de partida: como Mário pensa e conceitua a arte popular? Segundo ele, a idéia de arte popular não pode servir de álibi para qualquer tipo de sentimentalismo e facilidade, da mesma forma que é rejeitada a noção de uma arte que se pretenda vinculada a eternidade e não ao seu tempo. Entre estes opostos, Mário se equilibra na tentativa de criação de uma estética.

Também o engajamento artístico é visto por ele com ressalvas assim explicitadas: os artistas eruditos que se botam fazendo essa tal de "arte proletária", confundem o princípio de revolução com sentimentalismo. Confundem Charitas com a caridade esmoler. O povo, para eles, não passa duma superstição ${ }^{21}$. (parei aqui)

Isto não significa, contudo, o elogio da pura arte; para Mário, esta deve ser substituída pela arte-ação; um conceito que permitiria ao artista brasileiro atuar como filho duma nacionalidade que se afirma e dum tempo que está apenas começando. Caberia ao artista, assim, representar igualmente seu tempo e sua nação: sua nação no tempo. Tal ação deveria ser colocada acima de seus próprios interesses como artista, o que o leva a criar um princípio

21- ANDRADE, Mário de. O banquete. São Paulo, Duas Cidades, 1977, p.68

programático: sacrificar as nossas liberdades, as nossas veleidades e pretensões pessoais: e colocar como cânone absoluto da nossa estética, o princípio de utilidade. O PRINCÍPIO DE UTILIDADE $E^{22}$.

${ }^{21}$ ANDRADE, Mário de. Querida Henriqueta: cartas de Mário de Andrade a Henriqueta Lisboa . Op. Cit., p. 150 
Mário formula, assim, um princípio estético e ao mesmo tempo anseia por aplicá-lo à sua própria obra:

Minha revolta de Paulicéia, embora alguns tenham sentido também revoltas, não saiu universalizável; é um grito dum homem só, grito meu inconfundível. Ora, hoje eu quero gritar de tal forma que meu grito seja o de toda gente. Quero dizer, tornar o menos pessoal possível minhas coisas pra que se tornem gerais ${ }^{23}$.

No rebelde de 1922 e no defensor do verso livre podem soar deslocadas essas limitações impostas à liberdade criativa, mas já naquela época Mário recusava o individualismo em arte e apontava em carta a Manuel Bandeira, a necessidade do artista descer do pedestal e fazer concessões: e essa concessão é necessária, entretanto. É preciso acabar com esse individualismo e ser homem entre os homens. Hoje sou muito humilde. Meu maior desejo é ser homem entre os homens. Transfundir-me. Amalgamar-me. Ser entendido. Sobretudo isso. QUERO SER ENTENDIDO ${ }^{24}$.

22- ANDRADE, Mário de. O banquete. Op. Cit., p.130

23- ANDRADE, Mário de. A lição do amigo: cartas de Mário de Andrade a Carlos Drummond de Andrade. Rio de Janeiro, José Olympio, 1982, p.96

24- MORAES, Marcos Antônio de ( Org. ). Correspondência Mário de Andrade \& Manuel Bandeira. Op. Cit., p.101

Trata-se aqui de um texto publicado em um momento no qual a defesa da liberdade criativa, levada a efeito em pleno modernismo, torna-se atenta à necessidade de rigor estético e 
compromisso social. Como acentua Sérgio Buarque: um dos insistentes temas de Mário de Andrade em sua fase de crítico militante foi o da necessidade de reabilitar o esforço artístico e mesmo artesanal contra a valorização romântica do artista simplesmente irresponsável ${ }^{25}$.

Trata-se de um tema já implícito em carta a Drummond datada de 1926, na qual Mário crítica Oswald, seu comportamento e sua obra e afirma: a única censura até agora íntima que faço séria ao Osvaldo é justamente essa. Ele está mais perto de Graça Aranha do que imagina. Fez da vida um espetáculo de circo de que ele é o clown. Faz as graças e se ri ainda mais que os outros das próprias graças $^{26}$. Em Oswald, Mário vê o artista descompromissado que seria, paulatinamente, o principal alvo de suas críticas, substituindo o artista acadêmico que foi alvo do modernismo.

Por outro lado, a crítica às indigestões de sabedoria feitas por Oswald no Manifesto PauBrasil não são aceitas por Mário como o Manifesto de uma maneira geral não seria aceito por ele. Como salienta Santos em vários trechos da correspondência com Manuel Bandeira e Carlos Drummond de Andrade, principalmente, Mário repudia o manifesto atribuindo-lhe um caráter demolidor, como um texto que abala a harmonização do todo, colocando em questão

25- HOLANDA, Sérgio Buarque de. O espírito e a letra: estudos de crítica literária. São Paulo, Companhia das Letras, 1996, vol. II., p.242

26- ANDRADE, Mário de. A lição do amigo: cartas de Mário de Andrade a Carlos Drummond de Andrade. Op. Cit., p.91 o saber adquirido e a tradição cultural de um povo ${ }^{27}$. 
E por outro lado, Oswald procedeu a uma revisão e radicalização do modernismo, dando início a sua fase antropofágica da qual Mário manteve-se distante, sendo cobrado por isto até o ponto de ruptura. Segundo Boaventura:

Oswald, na Revista de Antropofagia, cobrava de seu companheiro determinado apoio irrestrito a figuras inexpressivas e também não admitia a defesa de certas posições políticas de caráter conservador. Reagia publicamente contra isso... Mário não quis aderir a fase agressiva da revista que implicava na derrubada de mitos dentro do próprio modernismo. Os antropófagos começaram a cobrar um posicionamento do amigo, primeiro em tom de troça. Com o passar do tempo, a maledicência tomou conta de algumas tiradas sarcásticas da revista. Da parte de Mário, então o rompimento foi para valer ${ }^{28}$.

Tal rompimento pode ser mais bem compreendido da parte de Mário, a partir de um artigo sobre Tristão de Ataíde escrito por ele em 1931, onde Mário defende a autonomia da arte em relação às instâncias políticas ou religiosas. Segundo ele, há um contraste insolúvel entre os detalhes duma religião ou sistema político e a criação artística ${ }^{29}$. Nas cobranças de Oswald,

27- SANTOS, Matilde Demétrio dos. A correspondência de Mário e a "felicidade" no credo modernista in Revista do Instituto de Estudos Brasileiros, Num 36. São Paulo, USP, 1994, p.104

28- BOAVENTURA, Maria Eugênia. O salão e a selva: uma biografia ilustrada de Oswald de Andrade. São Paulo/Campinas, Ex Libris/Editora da UNICAMP, 1995, p.142

29- ANDRADE, Mário de. Aspectos da literatura brasileira. Op. Cit., p.7

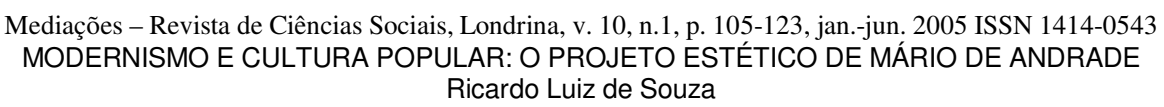


Mário viu entre outras coisas, uma ameaça à esta autonomia.

Mas, ao mesmo tempo, tal elogio da liberdade e autonomia artísticas deve ser matizado de forma que ao criticar o que considera uma interpretação errônea do modernismo baseada na liberdade formal, mas deixando de lado a competência técnica, Mário faz a distinção entre liberdade e facilidade: a liberdade artística não pode servir como pretexto para a facilidade formal.

Recusando de qualquer forma os princípios contidos no manifesto criado por Oswald, Mário manteve-se fiel a um pressuposto que sempre norteou sua atividade enquanto intelectual; para ele, o artista deve criar a partir de sua experiência e não a partir de princípios teóricos préestabelecidos. Segundo ele, os criadores geniais estabelecem um ou outro princípio teórico, mas esses princípios não têm para eles função básica de teoria. Exercem antes uma função normalizadora, estabilizadora de personalidade ou de tendências mais ou menos coletivas ${ }^{30}$. A arte é autônoma: não cabe a ela enquadrar-se em qualquer esquema teórico, mas cabe à teoria explicá-la.

O elogio da experiência significa também o elogio da pesquisa como ponto de partida para a criação da arte nacional. Isto porque Mário defende a criação de uma arte nacional que funcione como transposição da cultura popular. Em relação a música, por exemplo, ele afirma: o artista tem só que dar pros elementos já existentes uma transposição erudita que faça da música popular, música artística, isto é: imediatamente desinteressada ${ }^{31}$, o que não quer dizer obrigatoriedade de produzir-se música que tenha caráter étnico. Trata-se de utilizar o material popular não para mimetizá-lo, mas para produzir cultura erudita.

30- ANDRADE, Mário de.Música, doce música. São Paulo, Martins, 1963, p.30 
31- ANDRADE, Mário de. Ensaio sobre a música brasileira. São Paulo, Martins, 1962, p.16

A crítica de Mário aos compositores eruditos brasileiros incide exatamente neste ponto, esclarece e define sua importância no contexto de sua obra. Segundo Mário:

Esses autores tinham já fontes, embora escassas. Porque se resguardaram dentro duma nacionalidade, mas não tiveram sede nunca dessas fontes. Resultado: não acharam ninfa que os protegesse e hoje só encontram naqueles brasileiros que querem ser dum povo mais que das suas pessoinhas individuais e desprezíveis, memória e juízo frio" ${ }^{\text {32. }}$.

A diminuição da distância entre a cultura erudita e o povo somente seria possível a partir da apropriação por parte desta de elementos da cultura popular e o caminho a ser percorrido para que tal incorporação fosse possível seria o estudo sistemático das manifestações culturais populares e a incorporação de técnicas tradicionais de artesanato ao fazer artístico da arte erudita ${ }^{33}$.

Arte erudita e arte popular estruturam-se dialeticamente em um processo sintetizado por Florestan Fernandes:

As duas formas de arte imbricam-se numa relação dialética - tal como Mário de Andrade situa o problema: a arte erudita deve realizar-se na e através da

32- ANDRADE, Mário de. Modinhas imperiais. São Paulo, Martins, 1964, p.8

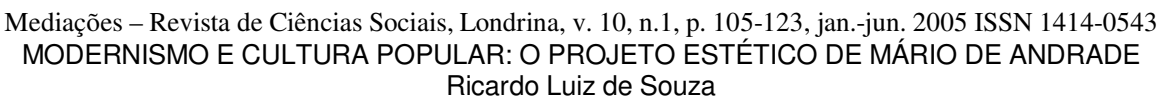


33- FACINA, Adriana. Arte nacional e educação estética em Mário de Andrade in REIS FILHO, Daniel Aarão ( Org. ) - Intelectuais, história e política: séculos XIX e XX. Rio de Janeiro, 7 Letras, 2000, p.162

arte popular - e a antítese, no caso a arte popular, cede o lugar a uma terceira forma de arte que do ponto de vista da fatura chama-se ainda arte erudita, mas que é uma coisa nova, mais essencial e mais expressiva ${ }^{34}$.

A relação entre cultura popular e erudita coloca em questão, ainda, o primitivismo andradeano. É preciso pensar o primitivismo existente na obra de Mário tendo em vista a pouca importância dada por ele a particularismos étnicos, no contexto da cultura brasileira, marcados pelo caldeamento das matrizes culturais. Como acentua Travassos: ele não tomava a sério propostas de uma cultura brasileira calcada em particularismos étnicos e combateu a inspiração exclusiva em criações aborígenes e africanas ${ }^{35}$, o que não invalida, contudo, o primitivismo como fonte de inspiração e como elo de ligação entre artista e nação: ligação indispensável à construção da própria nacionalidade.

Existe cultura erudita, mas não existem assuntos eruditos; assim como não existem exotismos. Esta é a lição do modernismo, segundo ele:

A impulsão lírica é livre, independe de nós, independe da nossa inteligência. Pode nascer de uma réstia de cebolas como de um amor perdido... Não há temas poéticos. Não há épocas poéticas. Os modernistas derruindo esses alvos mataram o último romantismo remanescente: o gosto pelo exótico $^{36}$.

34- FERNANDES, Florestan. O folclore em questão. São Paulo, HUCITEC, 1978, p.154

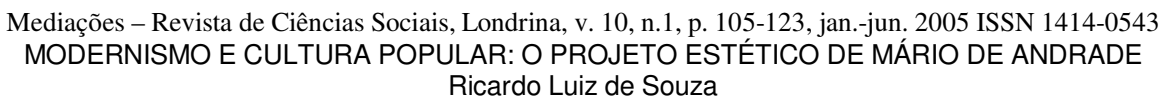


35- TRAVASSOS, Elizabeth. Os mandarins milagrosos: arte e etnografia em Mário de Andrade e Béla Bartók. Rio de Janeiro, Funarte/Jorge Zahar Editor, 1997, p.158 36- ANDRADE, Mário de. Obra imatura. São Paulo, Martins, 1960, p.208.9

Trata-se de um acerto de contas com o romantismo, especificamente com o indianismo: trata-se de incorporar à nacionalidade o que antes era visto como um exotismo histórico, e trata-se de incorporar a realidade à arte (sem que isto postule a criação de uma arte realista). Tal incorporação leva, finalmente, à busca de novos assuntos; assuntos dos novos tempos, o que transformaria o modernismo não em uma ruptura, mas na continuidade de uma tradição poética milenar. E Mário conclui a defesa do movimento, definindo-o como uma retomada da tradição:

Mas os poetas modernistas não se impuseram esportes, maquinarias, eloqüências e exageros como princípios de todo lirismo. Oh não! Como os verdadeiros poetas de todos os tempos, como Homero, como Vergílio, como Dante, o que cantam é a época em que vivem. E é por seguirem os velhos poetas que os poetas modernistas são tão novos ${ }^{37}$.

O caráter de contestação do modernismo, sua ênfase na destruição de tradições culturais o incomoda de fato, já em 1924, o que ele confessa a Manuel Bandeira em uma tentativa de exatamente reatar o fio com estas tradições e absorver suas influências: toda reação traz exageros. Eu tive porque fui reacionário contra o simbolismo. Hoje não sou. Não sou mais modernista. Mas sou moderno como você. Hoje eu já posso dizer que sou também um 
descendente do modernismo. O moderno evoluciona ${ }^{38}$. E alguns anos depois ele reafirma seu

37- ANDRADE, Mário de. Obra imatura. Op. Cit., p.224

38- MORAES, Marcos Antônio de ( Org. ). Correspondência Mário de Andrade \& Manuel Bandeira. São Paulo, EDUSP/IEB, 2001, p.169

apego às tradições que ele, enquanto modernista, pretensamente empenhara-se em destruir: dizem que sou modernista e... paciência! O certo é que jamais neguei as tradições brasileiras, as estudo e procuro continuar a meu modo dentro delas ${ }^{39}$. E de resto, Mário confessa já no Prefácio Interessantíssimo colocado no pórtico do modernismo, seu apego à tradição, quando afirma: sou passadista, confesso ${ }^{40}$.

Mesmo o caráter destrutivo do modernismo termina, retrospectivamente, sendo alvo de críticas de Mário ao ser definido como imprudência literária e criticado enquanto tal. E ele toma a si próprio como exemplo para efetivar tal crítica: livros, por exemplo, como o Losango cáqui e o Clã do Jabuti para só atacar quem posso, mostram uma tal imprudência de atitudes, de atitude poética, de atitude intelectual, que são dos melhores exemplos de destrutivismo e desencaminhamento que se possa dar ${ }^{41}$.

O elogio ao modernismo cederia lugar, ainda, a uma revisão não raro impiedosa feita de forma pública e particular. Sua própria participação no movimento é definida como essencialmente imatura: na verdade, o meu espírito só se principia demonstrando algum (apenas “algum”) equilíbrio de maturidade ali por 1926/27. E só já não tem mais propriamente razão pra se envergonhar de si e das burradas que faz (burradas, mas já harmoniosas ) depois de $1932^{42}$. 
Já em 1932 Mário relativiza o impacto transformador do modernismo sobre a produção

39- ANDRADE, Mário de. Mário de Andrade-Oneyda Alvarenga: cartas. São Paulo, Duas Cidades, 1983a

40- ANDRADE, Mário de. Poesias completas, São Paulo, Martins, 1974, p.14

41- ANDRADE, Mário de. Mundo musical in COLI, Jorge - Música final: Mário de Andrade e sua coluna jornalística. Op. Cit., p.7

42- ANDRADE, Mário de. Querida Henriqueta: cartas de Mário de Andrade a Henriqueta Lisboa . Op. Cit, p.133

cultural brasileira, afirmando: com o "modernismo" mudou-se a maneira de versejar, se espevitou mais um bocado o jeito de dizer. Enfeitou-se a nossa escrita de brasileirismos vocabulares, grande mudança; na verdade o intelectual brasileiro continua tocandinho na viola o toque rasgado da sua pasmosa inércia humana ${ }^{43}$.

Na conferência sobre o movimento modernista, Mário reconhece, finalmente, o fracasso do projeto no qual se empenhara: na verdade, apesar da aparência e da bulha que fazem agora certas santidades de última hora, nós estamos ainda atualmente tão escravos da gramática lusa como qualquer português ${ }^{44}$.

Fazendo um exame crítico do modernismo em carta escrita em 1941, Mário identifica duas fases no movimento: uma fase de rebeldia, contestação e hostilidade, na qual um grupo pequeno e unido era insultado e combatido e se considerava genial. Ali, nos retratos pintados por Anita Malfati ele se descreve e descreve seus companheiros: sou bem eu e somos bem nós daqueles tempos, gente em delírio, lançada através de todas as maluquices divinas e minha magreza espigada, um pouco com ar messiânico de quem jejuou quarenta dias e quarenta noites $^{45}$. Mas chegou a fase seguinte, onde se afirmou o reconhecimento, que trouxe $a$ 
desilusão da vitória e com ela, o fortalecimento da consciência crítica e, finalmente, a dissolução do grupo: já nos examinávamos com maior franqueza e verdade, já nos

43- ANDRADE, Mário de. Táxi e crônicas no Diário Nacional. Op. Cit., p.515

44- ANDRADE, Mário de. Aspectos da literatura brasileira. Op. Cit., p.244

45- ANDRADE, Mário de. Querida Henriqueta: cartas de Mário de Andrade a Henriqueta Lisboa . Op. Cit., p.52

entrecriticávamos, já nos chegávamos à frígida calma de não gostar ${ }^{46}$.

Mesmo na primeira fase, entretanto, Mário termina em carta escrita no mesmo ano por não reconhecer a existência de um espírito de grupo, predominando sobre tal espírito que acabou por não se concretizar, as buscas individuais. E referindo-se ao movimento, ele afirma: $o$ que não existe é o "espírito social", a consciência do grupo, a forma da coletividade. A Dádiva. Cada qual se buscou, fazendo de si o Brasil, o Mundo. Daí uma ausência de "cultura”, no seu mais elevado sentido, uma realidade coletiva ${ }^{47}$.

Faltaram aos modernistas, assim, a consciência e a vontade de fazerem um grupo, e Mário constata e ressente-se desta característica do movimento no final de sua vida. Escrevendo a Otto Lara Resende em 1944, ele o saúda e a seus companheiros exatamente por fazerem um grupo, e constata: e os meus companheiros de geração, guardo deles este ressentimento, ainda vinham oitocentisticamente tão apegados ao exercício do individualismo, nesta terra sem tradições, nem raciais nem culturais, que jamais pudemos viver os benefícios, os confortos, as forças do grupo $^{48}$. Cria-se, assim, uma situação ambígua: contestador em 
relação as tradições existentes, faltando ao modernismo exatamente uma tradição que o consolidasse e o amalgamasse enquanto grupo.

O modernismo sempre foi visto por Mário como uma herança ambígua, nunca inteiramente aceita, muitas vezes vista com desconfiança, mas sempre defendida de acusações, embora tal

46- ANDRADE, Mário de. Querida Henriqueta: cartas de Mário de Andrade a Henriqueta Lisboa . Op. Cit., p.52

47- ANDRADE, Mário de. A lição do amigo: cartas de Mário de Andrade a Carlos Drummond de Andrade. Op. Cit., p.61

48- ANDRADE, Mário de. Carta aos mineiros. Belo Horizonte, Editora UFMG, 1997, p.146

defesa seja sempre feita com ressalvas. Promessas feitas pelo modernismo não vingaram e aqueles rapazes literatos de São Paulo que a semana de Arte moderna lançou em $1922^{\underline{49}}$ desapareceram de modo que em 1939, Mário se pergunta por eles, embora ele próprio tenha sido um deles. Ele aceita o fato de alguns maus modernistas terem se insurgido contra a cultura e aceita a acusação dos modernistas não terem construído nada ${ }^{50}$. Mas tenta justificar o movimento: a sua função não foi construtiva e seu objetivo foi abrir caminhos, servir como arauto. E isto ele fez:

O Modernismo foi um toque de alarme. Todos acordaram e viram perfeitamente as auroras no ar. A aurora continha em si todas as promessas do dia, só que ainda não era o dia. Mas é uma satisfação ver que o dia está cumprindo com grandeza a maior fecundidade, as promessas da aurora. Ficar nas eternas aurorices da infância, não é saúde, é doença. E a literatura brasileira aí está, bastante sã. Adulta já? Quase adulta ${ }^{51}$. 
O modernismo foi assim, na perspectiva andradeana, uma etapa; indispensável, mas que pedia sua superação. Foi uma etapa aristocrática, isenta dos sacrifícios, que Mário reputou mais tarde serem indispensáveis à condição de artista. Foi uma etapa lúdica, sem sofrimentos. Foi também um movimento marcado por contradições. Recusou o parnasianismo por purista, mas privilegiou a autonomia do artista. Buscou resgatar a autenticidade da preguiça

49- ANDRADE, Mário de. O empalhador de passarinhos. São Paulo, Martins, 1972, p.23

50- ANDRADE, Mário de. O empalhador de passarinhos. Op. Cit, p.104

51- ANDRADE, Mário de. O empalhador de passarinhos. Op. Cit, p.189

macunaímica ou do antropófago oswaldiano a partir de influências européias e manteve uma postura permanente de contestação cultural - o espírito destruidor ao qual Mário se refere ou o boêmio em oposição a burguesia na expressão de Oswald - sem contestar as estruturas sócioeconômicas que geraram o movimento.

Consciente de tais contradições, Mário, e Oswald por outros caminhos - buscou repensá-las ao longo de sua obra. E a análise permanente de tais contradições, o conduzem no final ao pessimismo e à desilusão quanto ao movimento e quanto a ele próprio; inseparáveis que são, no final das contas. Sua conferência sobre o movimento feita em 1942 é uma condenação tanto do movimento quanto de seu passado enquanto homem e enquanto intelectual: uma dolorosa catarse na qual ele vê seu passado como traidor e suas ilusões e esperanças desfeitas.

A principal virtude do modernismo, mais de uma vez ressaltada por Mário foi, legar ao artista brasileiro o direito de pesquisar e errar. Como ele acentua: já não falo apenas desse direito, afirmado pela Semana de Arte Moderna de pesquisa dentro do atual e do novo, do 
direito de errar, enfim, que só exatamente a virgindade pode $t e r^{52}$. E que virgindade é esta, afinal? É a virgindade em relação a própria realidade brasileira tornada acessível, enfim, a partir das pesquisas modernistas. Escrito em 1932, este trecho reflete uma avaliação positiva do modernismo que não iria, contudo, ser mantida por Mário e cederia lugar, nos anos quarenta, a uma amarga reavaliação do movimento. Neste período final de sua obra, o julgamento da geração que iria promover o modernismo - a sua geração- já era contundente:

52- ANDRADE, Mário de. Aspectos da literatura brasileira. Op. Cit. , p.47

A minha pífia geração era afinal das contas o quinto ato conclusivo de um mundo e representava bastante bem a sua época dissolvida nas garoas de um impressionismo que alagava as morais como as políticas. Uma geração de degeneração aristocrática, amoral, gozada, e apesar da revolução modernista, não muito distante das gerações de que ela era o "sorriso" final $l^{53}$.

Esta reavaliação crítica do modernismo, e por conseqüência de sua geração e de sua própria obra, teria como síntese e como ápice a conferência intitulada $O$ movimento modernista proferida em 1942: palavras de um autor frustrado e descontente com sua própria obra, amargo em relação ao movimento do qual participou, desiludido em relação aos sonhos e diretrizes que orientaram toda sua trajetória.

Mota aponta três facetas que considera fundamental na conferência: a crítica aos registros aristocratizantes de sua atividade e das de seus companheiros por ele próprio apontados; o 
caráter propriamente político de sua conferência; e a marca ideológica nacionalista (que direta ou indiretamente atravessou seus contemporâneos) $)^{54}$.

Logo de início, ele tenta definir o sentido do movimento: manifestado especialmente pela arte, mas manchando também com violência os costumes sociais e políticos, o movimento modernista foi o prenunciador, o preparador e por muitas partes o criador de um estado de espírito nacional ${ }^{55}$. Esta foi sua função e esta foi sua herança; uma herança que se estruturou

53- ANDRADE, Mário de. Aspectos da literatura brasileira. Op. Cit. , p.192

54- MOTA, Carlos Guilherme. Ideologia da cultura brasileira: pontos de partida para uma revisão histórica. São Paulo, Ática, 1977, p.

55- ANDRADE, Mário de. Aspectos da literatura brasileira. Op. Cit. , p.231

a partir de três princípios fundamentais: o direito permanente à pesquisa estética; a atualização da inteligência artística brasileira, e a estabilização de uma consciência criadora nacional ${ }^{56}$. O modernismo abriu espaço ainda para manifestações culturais que eclodiam a nível regional - como por exemplo, os verdes de Cataguases - sistematizando a cultura brasileira até então concentrada nos grandes eixos urbanos ${ }^{57}$. E, principalmente, o modernismo inventou a liberdade e deixou-a como herança: e hoje o artista brasileiro tem diante de si uma verdade social, uma liberdade (infelizmente só estética), uma independência, um direito às suas inquietações e pesquisas, que não tendo passado pelo que passaram os modernistas da Semana, ele nem pode imaginar que conquistas enormes representam ${ }^{58}$.

Este foi o legado do modernismo e poderia parecer suficiente, mas para Mário não é. A geração modernista - a sua - foi para Mário, vítima de sua própria despreocupação e de seu próprio hedonismo. Vítimas do próprio prazer assumiram uma postura desinteressada perante 
os problemas de seu tempo, que vinte anos depois soa para Mário como uma condenação. E ele conclui:

Atuais, atualíssimos, universais, originais mesmo por vezes em nossas pesquisas e criações, nós os participantes do período, milhormente chamado “modernista”, fomos com algumas exceções nada convincente, vítimas do nosso prazer da vida e da festança em que nos desvirilizamos. Se tudo

56- ANDRADE, Mário de. Aspectos da literatura brasileira. Op. Cit. , p.242

57- ANDRADE, Mário de. Aspectos da literatura brasileira. Op. Cit. , p.248

58- ANDRADE, Mário de. Aspectos da literatura brasileira. Op. Cit. , p.251

mudávamos em nós, uma coisa nos esquecemos de mudar: a atitude interessada diante da vida contemporânea. E isto era o principal! ${ }^{59}$.

A crítica andradeana ao modernismo só faz sentido, finalmente, se contextualizada a partir do projeto estético e cultural que Mário buscou desenvolver. O modernismo é criticado a partir do momento em que destoa deste projeto. E faz parte do projeto cultural de Mário e ajuda a explicá-lo o projeto de escrever uma Gramatiquinha da Língua Brasileira, projeto acalentado nos anos 20 e abandonado nos anos 30, exatamente quando seu engajamento nos estudos sobre o folclore aprofundam-se ${ }^{60}$. Faz parte deste projeto mais amplo, ainda, seu interesse pela música brasileira: através dela, ele busca a decodificação de uma linguagem 


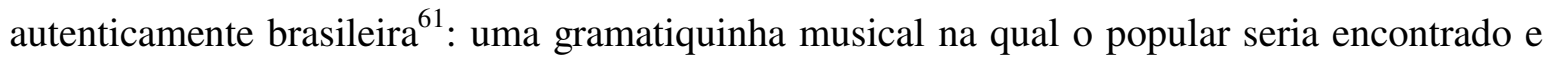
valorizado.

A língua nacional ideada por Mário tem correspondente, por exemplo, como lembra Scwhartz, no idioma dos argentinos pensado no mesmo período por Borges e em outros projetos delineados na América Latina no mesmo período; e corresponde ainda, segundo Scwhartz, a um esforço capaz de aglutinar grande parte das expressões dialetais do Brasil para chegar a uma síntese representativa das peculiaridades linguísticas de todas as regiões do país ${ }^{62}$.

59- ANDRADE, Mário de. Aspectos da literatura brasileira. Op. Cit. , p.252

60- ELIA, Sílvio. El portugués en Brasil: historia cultural. Madrid, Editorial MAPFRE, 1992, p.207.8

61- NEVES, Margarida de Souza. Da maloca do Tietê ao Império da Mata Virgem. Mário de Andrade: roteiros e descobrimentos in CHALHOUB, Sidney \& Pereira, Leonardo Affonso de M. ( Org. ) - A história contada: capítulos de história social da literatura no Brasil. Rio de Janeiro, Nova Fronteira, 1998, p.269

62- SCWHARTZ, Jorge. Introdução in SCWHARTZ, Jorge (Org. ) - Vanguardas latino-americanas: polêmicas, manifestos e textos críticos. São Paulo, Iluminuras/EDUSP/FAPESP, 1995, p.45

Tal projeto encontra, porém, um obstáculo: falta originalidade à civilização brasileira. Ela é, na expressão de Mário, uma civilização de empréstimo cujo desenvolvimento é artificial e mais ou menos forçado. Falta a ela, inocência. A música, por exemplo, não teve como se desenvolver livre de preocupações quanto à afirmação social e nacional. Ela teve que instrumentalizar-se para alcançar seus objetivos e tal postura gerou em algumas ocasiões, o artifício e a imitação. É o caso, no terreno da poesia, do parnasianismo, e daí Mário tomá-lo como alvo preferencial. Para ele, o parnasianismo foi uma excrescência explicável, mas derrotista, fruto legítimo de cultura ingênua e mais ou menos falsa, provocada pelo artificialismo obrigatório das nossas civilizações importadas, americanas ${ }^{63}$. 
Em contraste com tal tentativa de imitação - derrotista, porque abandona a tentativa de criar uma cultura que tente traduzir sua nacionalidade; que foge da raia buscando um atalho que leva diretamente à Europa sem a intermediação que torna legítima a importação e adaptação de padrões europeus - Mário propõe uma inspiração que não almeje livrar-se da nacionalidade, mas que a traduza. O alvo agora é a pretensão de se criar uma música que seja universal e, mirando tal alvo, Mário afirma:

Não há música internacional e muito menos música universal; o que existe são gênios que se universalizam por demasiado fundamentais, Palestrina, Bach, Beethoven ou mulheres que se internacionalizam por demasiado fáceis, a "Traviata", a "Carmen", "Butterfly". Porém, mesmo dentro desta internacionalidade ou daquela universalidade, tais músicos e tais mulheres não deixam nunca de ser funcionalmente nacionais ${ }^{64}$.

63- ANDRADE, Mário de. Aspectos da música brasileira. São Paulo, Martins, 1965, p.16 64- ANDRADE, Mário de. Aspectos da música brasileira. Op. Cit., p.29

E que mediação é esta? Trata-se de levar a cabo, a tentativa de afirmação nacional pela mediação do universal da condensação e deslocamento dos valores europeus com os valores brasileiros $^{65}$. Mas a criação de uma arte nacionalista ainda é uma etapa a ser superada: ela terá que se elevar ainda um dia à fase que chamarei de Cultural, livremente estética, e sempre se entendendo que não pode haver cultura que não reflita as realidades profundas da terra em que se realiza ${ }^{66}$. O nacionalismo de Mário é no contexto de uma cultura que se instrumentaliza, como afirmação da nacionalidade, também instrumental. Busca a criação de 
uma cultura que seja ao mesmo tempo livre e nacional. Mas para ser finalmente livre, inicialmente, ela precisa ser nacional.

Trata-se de idéia fundamental na obra de Mário e retomada quase textualmente em obra, durante longo tempo inédita, mas escrita já nos anos 40. Em uma longa reflexão sobre a arte, ele reafirma a importância de criação de uma arte nacional:

O compositor brasileiro que perder o folclore nacional de vista e de estudo será o que vocês quiserem, mas fatalmente se desnacionalizará e deixará de funcionar. Desse ponto de vista, todos os artistas que importam no Brasil de hoje são de fato os que ainda tem como princípio pragmático de sua criação fazer música de pesquisa brasileira. A invenção livre só virá mais tarde, quando a criação musical erudita estiver tão rica, complexa e explícita em suas

65- SOUZA, Eneida Maria de. Preguiça e saber in AYALA, Maria Ignez Novaes \& Duarte, Eduardo de Assis (Orgs.) - Múltiplo Mário: ensaios. Natal/João Pessoa, Editora da UFRN/UFPB, 1997, p.140 66- ANDRADE, Mário de. Aspectos da literatura brasileira. Op. Cit. , p.34

tendências particulares psicológicas, que o compositor possa desde a infância viver cotidianamente dentro dela, se impregnar dela e a sentir como instinto ${ }^{67}$.

E a criação desta cultura é definida por ele como uma tarefa tão urgente como alimentar o povo brasileiro. Reflete-se aqui, a dolorosa experiência pública de Mário, quando ele conclui em Oração de Paraninfo proferida em 1935: a uma iniciativa cultural todos se queixam, 
porque faltam hospitais ou porque a situação financeira não permite luxos... Nós não estamos convencidos de que a cultura vale como o pão. E essa é a nossa mais dolorosa imoralidade cultural $^{68}$.

Só é nacional o que é vivo, o que está vivo e é expresso na cultura popular. Segundo Mário, a lingua realmente viva, a que vive pela boca, e é irredutível a sinais convencionais, é o que dá o sentido expressional duma nacionalidade ${ }^{69}$.

A função do artista então, deve ser a de construir uma arte nacional, mas tal construção não pode ser feita de forma arbitrária, e o artista não pode construí-la a partir de critérios livremente definidos por ele. Pelo contrário, uma arte nacional não se faz com escolha discricionária e diletante de elementos: uma arte nacional já está feita na inconsciência do povo $^{70}$. E daí, conclui Mário, o critério de nacionalidade ser válido, urgente e imperioso como critério de validação artística. Para ele, todo artista brasileiro que no momento atual fizer arte brasileira é um ser eficiente com valor humano. O que fizer arte internacional ou estrangeira,

67- ANDRADE, Mário de.O banquete. Op. Cit., p.151

68- ANDRADE, Mário de. Aspectos da música brasileira. Op. Cit., p.245

69- ANDRADE, Mário de. Aspectos da música brasileira. Op. Cit., p.122

70- ANDRADE, Mário de. Ensaio sobre a música brasileira. Op. Cit., p.16

se não for gênio, é um inútil, um nulo. Ee é uma reverendíssima besta ${ }^{71}$.

Quando Mário detém-se na análise da cultura de massas de seu tempo em área especialmente cara a ele - a música - é para contrapô-la desfavoravelmente à autenticidade da cultura popular, no caso, fazendo o contraponto entre o samba de morro carioca e o maracatu recifense. Referindo-se a este samba, ele não estabelece nenhuma ligação entre a música radiofônica e a popular, limitando-se a desqualificar a primeira. Segundo ele, trata-se 
exatamente de uma sub música, carne para alimento de rádios e discos, elemento de namoro e interesse comercial com que fábricas, empresas e cantores se sustentam, atucanando a sensualidade fácil de um público em vias de transe ${ }^{72}$. Não são reconhecidas, precisamente, as origens populares do tipo de música por ele criticada; como se a cultura popular fosse naturalmente desfigurada e desvalorizada ao passar pelo filtro da produção comercial.

A cultura popular brasileira - especialmente a música - sofreu um processo de apropriação pela burguesia que a desfigurou, transformando-a na música instrumental que ela originalmente nunca foi, criando formas espúrias e hesitantes. Mas o samba especialmente que Mário define como a nossa dança popular urbana permanece autêntico em territórios inexplorados pela burguesia e pela indústria cultural em um processo de resistência e preservação, que é para Mário, de essencial importância. E ele conclui: Felizmente, no ar mais alto dos morros, o samba continuava a batucar, ignorado, formando-se com mais liberdade e pureza, na fraternidade das macumbas e dos cordões de carnaval ${ }^{73}$.

A cultura popular defendida e pesquisada por Mário caminha à margem dos incipientes meios de comunicação de massa existentes no período, especificamente o rádio, da mesma

71- ANDRADE, Mário de. Ensaio sobre a música brasileira. Op. Cit., p.19

72- ANDRADE, Mário de.Música, doce música. Op. Cit., p.281

73- ANDRADE, Mário de.Música, doce música. Op. Cit., p.323

forma como o modernismo construíra um universo a parte em relação ao humor paulista, criado por cronistas e humoristas do início do século, embora estes apresentassem um olhar com características modernistas, como salienta Saliba, desenvolvido nos anos 30 pelo humor macarrônico (que recriava, no Brasil, uma tradição renascentista elaborada por Folengo) do longamente esquecido Juó Bananaré, definido por Carpeaux como precursor do modernismo 
para o qual contribui, desmoralizando os deuses parnasianos $^{74}$. Mário menciona e relega, contudo, ao segundo plano, toda esta tradição subterrânea, conclui Saliba:

Mas para além da forte caracterização algo pejorativa de Mário de Andrade e independente dela, não teríamos já aí, a tal "língua popular” que o mesmo Mário de Andrade tanto lutara para encontrar na sua vasta obra? Não teríamos aí, a marca daquele "ruim gostoso", que segundo ele próprio seria a marca popular da brasilidade $e^{75}$.

Ao pensar a cultura popular, Mário nos remete inevitavelmente ao conceito - amorfo por definição - de povo. Pensando tal cultura como expressão popular, Mário limita-se a fazer uma sumária divisão entre cidade e campo, mas ignora as demais estratificações contidas nesta divisão dual e termina pensando a nação como uma unidade, ignorando clivagens políticas, econômicas e culturais, conflitos e tensões correspondentes. A nação, a partir daí, age e reage como um todo e cabe ao artista exprimí-la em sua totalidade (como faz o próprio Mário com sua preocupação em criar uma linguagem brasileira a partir de regionalismos e locuções particulares).

74- CARPEAUX, Otto Maria . Reflexo e realidade. Rio de Janeiro, Fontana, s.d., p.249

75- SALIBA, Elias Thomé. Cruzamentos, encontros e sincretismos humorísticos na história brasileira dos anos vinte e trinta in Dimensões, Num. 12. Vitória, Departamento de História da UFES, 2001, p.117

Como definir então, a partir desta tipologia, o que seria música popular? Segundo Travassos, na perspectiva de Mário, a música popular é por definição, pura, coletiva e coletivizadora, 
socialmente funcional. Aquela praticada por indivíduos das classes sociais desfavorecidas que não portam tais características é de origem culta ou semiculta ${ }^{76}$.

E o próprio Mário preocupa-se em fazer tal distinção:

Uma diferença que pelo menos em música, ajuda bem a distinguir o que é apenas popularesco como o samba carioca do que é verdadeiramente popular, verdadeiramente folclórico, como o "Tutu Marambá", é que o popularesco tem por sua própria natureza, a condição de se sujeitar a moda. Ao passo que na coisa folclórica, que tem por natureza ser "tradicional" (mesmo transitoriamente tradicional), o elemento moda, a noção da moda está excluída ${ }^{77}$.

Algumas vertentes então finalmente se cruzam: a preocupação em resgatar a cultura popular e em utilizá-la como fundamento para a criação artística, a preocupação em preservar a pureza desta cultura, a partir da exclusão de modismos e da intransigente separação entre cultura de massas e cultura popular, a constatação da ausência de uma tradição erudita, a recusa ao mesmo tempo de uma arte livre de compromissos, de uma arte que faça concessões ao popularesco, de imposições que ameacem a autonomia do artista.

76- TRAVASSOS, Elizabeth. Os mandarins milagrosos: arte e etnografia em Mário de Andrade e Béla Bartók. Rio de Janeiro, Funarte/Jorge Zahar Editor, 1997, p.172

77- ANDRADE, Mário de. Mundo musical in COLI, Jorge - Música final: Mário de Andrade e sua coluna jornalística. Op. Cit.p.178 